\title{
Community Analysis of Endophytic Bacteria from the Seeds of the Medicinal Plant Panax notoginseng
}

\author{
Shuai $\mathrm{Liu}^{1, \uparrow}$, Dinghua $\mathrm{Li}^{1, \dagger}$, Xiuming Cui ${ }^{1}$, Limei $\mathrm{Chen}^{1} \&$ Hongjuan Nian ${ }^{1}$ \\ ${ }^{1}$ Faculty of Life Science and Technology, Kunming University of Science and Technology, Kunming Key \\ Laboratory of Sustainable Development and Utilization of Famous-Region Drug, Key Laboratory of Panax \\ notoginseng Resources Sustainable Development and Utilization of State Administration of Traditional Chinese \\ Medicine, Kunming, China \\ Correspondence: Hongjuan Nian, Faculty of Life Science and Technology, Kunming University of Science and \\ Technology, Kunming, China. Tel: 86-871-6592-0213. E-mail: hjnian@163.com
}

\author{
Received: November 1, 2016 \\ Accepted: December 3, 2016 \\ Online Published: January 15, 2017 \\ doi:10.5539/jas.v9n2p37 \\ URL: http://dx.doi.org/10.5539/jas.v9n2p37
}

${ }^{\dagger}$ Shuai Liu and Dinghua Li contributed equally to this work.

\begin{abstract}
Panax notoginseng is a traditional Chinese medicine. The roots of $P$. notoginseng can be used for treatment of diseases and raw materials in Chinese medicinal products. High yield and quality roots require cultivation in shade and humid conditions for 3 years. The long period cultivation makes $P$. notoginseng vulnerable to infect by pathogens. So control diseases are vital for the high yield and quality of $P$. notoginseng. The seed is the carrier systems of many probiotics and pathogens. To explore the indigenous bacterial community diversity, the endophytic bacteria from the seeds of the medicinal plant $P$. notoginseng were isolated and identified using traditional cultivation methods in combination with molecular technique. A total of 137 endophytic bacteria strains were isolated. The 16S rDNA of these strains was amplified and subjected to amplified ribosomal DNA restriction analysis (ARDRA) with restriction enzyme HaeIII. All the isolated strains were grouped into 9 OTUs (Operational Taxonomic Units) on the basis of the similarity of the ARDRA band profiles. Each representative strain of 9 OTUs was selected for sequencing. $\gamma$-proteobacteria was the most dominant group among the isolates (98.5\%), containing eight genera. Pseudomonas was the most dominant genus (58 of 135 isolates), whose isolates occurred in the seeds collected from all three places. The second dominant genus was Enterobacter (20.7\%), followed by uncultured bacterium (14.8\%) and Stenotrophomonas (10.4\%). Among the six areas sampled, endophytic bacteria in the seeds collected from Panlong of Yanshan exhibited species diversity and contained the most isolates. These results suggest an abundant diversity of bacterial community within the seeds of $P$. notoginseng. These data provide insights into monitoring the seed health and disease outbreak during seeding.
\end{abstract}

Keywords: ARDRA, endophytic bacteria, diversity, OTUs, Panax notoginseng

\section{Introduction}

Endophytic bacteria ubiquitously inhabit a majority of plant species (Lodewyck et al., 2002). These organisms can be isolated from surface-disinfected plant tissues, including seeds, roots, stems and leaves and are not harmful to the hosts (Hallmann et al., 1998). Endophytic bacteria may promote plant growth and suppress plant diseases (Feng et al., 2006). Several studies have reviewed endophytic bacteria community structures and their potential biological functions (Senthilkumar et al., 2011; Sturz et al., 2000).

Panax notoginseng is a traditional Chinese medicine plant specifically grown in the Wenshan region of Yunnan Province. The root of $P$. notoginseng is often used to treat cardiovascular diseases, inflammation, different body pains, trauma, and internal and external bleeding due to injury (Sun et al., 2005). P. notoginseng is a 3-year-old plant. High quality roots require 3-year cultivation in the shade and humid conditions. The long period growth makes $P$. notoginseng vulnerable to be infected by pathogens. The root-rot disease is the most destructive one (Sun et al., 2004), which was caused by soil-borne fungal pathogens (including Alternaria panax, Alternaria tenuis, Cylindrocarpon destructans, Cylindrocarpon didynum, Fusarium solani, Fusarium oxysporum, 
Phytophthora cactorum, Phoma herbarum and Rhizoctonia solani), bacterial pathogens (Pseudomonas sp. and Ralstonia sp.), and parasitic nematodes (such as Ditylenchus sp., Rhabditis elegans and Meloidogyne spp.) (Miao et al., 2006). Control diseases are vital for the high yield and quality of $P$. notoginseng.

The seeds of plants are the carrier systems of many probiotics and pathogens that play an important role in formation of rhizosphere microbial communities (Patkowska, 2001). However, studies concerning the interaction of the microbial community and plant seed genotype are lacking. Therefore, a better study of endophytic bacteria may help increase the current understanding of their function and potential role for the development of a more sustainable system for crop production. Few studies concerning endophytic bacterial community structures and their biological functions in Panax spp. have been reported, with the exception of reports on the endophytic bacterial community (Cho et al., 2007; Vendan et al., 2010). Ma et al. (2013) isolated 1000 endophytic bacterial strains from the root, stems, petioles, leaves and seeds of $P$. notoginseng, of which 104 strains exhibited antagonistic properties against at least one of three major pathogens ( $F$. oxysporum, Ralstonia sp. and Meloidogyne hapla) related to the root-rot disease of $P$. notoginseng. Therefore, knowledge concerning the endophytic bacterial structures and species is vital for the growth of Panax plants, the monitoring of seed health and the control of seedling disease. Thus, the aims of the present study were to characterize the endophytic bacteria present in the seeds of the medicinal plant $P$. notoginseng, to obtain a better understanding of endophytic bacterial community structures and diversities and to identify potential biological control candidates against pathogens leading to seedling and root diseases.

\section{Materials and Methods}

\subsection{Microorganisms and Culture Conditions}

The bacterial strains were cultured on Luria-Bertani (LB) solid medium (peptone $10 \mathrm{~g}$, yeast extract $5 \mathrm{~g}, \mathrm{NaCl} 10$ $\mathrm{g}$, agar powder $15 \mathrm{~g}$, and distilled water $1000 \mathrm{~mL}, \mathrm{pH} 7.2$ ) or in LB liquid broth at $37^{\circ} \mathrm{C}$.

\subsection{Isolation and Purification of Endophytic Bacteria}

The seeds were collected from 1-3-year-old healthy $P$. notoginseng plants, cultivated in Yanshan County, Maguan County, Guangnan County, Xichou County, Wenshan County and Qiubei County of the Wenshan region, Yunnan Province, China.

The samples were disinfected according to Li et al. (2010), with some modifications. The seeds were rinsed three times with sterile water, and subsequently, the moisture was absorbed using filter paper. The seeds were sterilized with $70 \%$ ethanol for $3 \mathrm{~min}$, immersed in $2.6 \%$ sodium hypochlorite solution for $5 \mathrm{~min}$, soaked in $70 \%$ ethanol for $30 \mathrm{~s}$, and subsequently washed three times with sterile water. The water samples of the last rinse were inoculated onto LB agar plates as a negative control. Simultaneously, the surface sterilized seeds were pressed onto an LB agar plate to test the sterilization efficiency. The seeds that were not detected as contaminated by cultivable microorganisms were considered successfully surface disinfected and were subsequently used for the isolation of endophytic bacteria (Schulz et al., 1993).

The surface sterilized seeds were divided into three groups. Five seeds in each group were homogenized with 2 $\mathrm{mL}$ of sterile water. The homogenates were diluted 1000 -fold, and $100-\mu \mathrm{L}$ dilutions were then spread onto LB agar plates. Each sample was replicated three times. The plates were cultured at $37{ }^{\circ} \mathrm{C}$ for $72 \mathrm{~h}$. The bacterial colonies with obvious morphological differences were purified. Colonies without distinct morphological differences were randomly selected.

\subsection{DNA Extraction from Bacteria}

The purified strains were inoculated in LB liquid medium and shaken at $200 \mathrm{rpm}$ for $12 \mathrm{~h}$ at $37^{\circ} \mathrm{C}$. The cultures were centrifuged and subsequently collected. Genomic DNA was extracted using the Genomic DNA Purification Kit (TIANGEN Biotech, Beijing, China) according to the manufacturer's instructions.

\subsection{Amplification of the Bacterial $16 S$ rRNA Gene}

The genomic DNA was used as the PCR template. A pair of primers, 799f and 1492r [13], were used to amplify the $16 \mathrm{~S}$ rDNA. In total, a $20-\mu \mathrm{L}$ PCR reaction mixture contained $1 \mu \mathrm{L}$ of genomic DNA, $1 \mu \mathrm{L}$ of each primer $(10$ $\mu \mathrm{M}$ ), and $1 \mu \mathrm{L} 2 \times$ Es Taq MasterMix (Es Taq DNA Polymerase, $2 \times$ Es Taq PCR buffer, $3 \mathrm{mM} \mathrm{MgCl}_{2}$, and 400 $\mu \mathrm{M}$ dNTP) (ComWin Biotech, Beijing, China). After initial denaturing at $94{ }^{\circ} \mathrm{C}$ for 3 min, thermal cycling proceeded with, denaturing at $94{ }^{\circ} \mathrm{C}$ for $30 \mathrm{~s}$, annealing at $50{ }^{\circ} \mathrm{C}$ for $30 \mathrm{~s}$, and elongation at $72{ }^{\circ} \mathrm{C}$ for $45 \mathrm{~s}$. At the end of 30 cycles, a final extension step was performed at $72{ }^{\circ} \mathrm{C}$ for $10 \mathrm{~min}$. 


\subsection{Amplified Ribosomal DNA Restriction Analysis (ARDRA)}

The specificity of the PCR product was examined on an agarose gel. The specific PCR product was used for digestion. The PCR product was completely digested with restriction enzyme HaeIII (NEB, Beijing, China), an enzyme that identifies four bases. The reaction mixtures contained $2 \mu \mathrm{L}$ of $10 \mathrm{X}$ incubation buffer, $2 \mu \mathrm{L}$ of HaeIII $(10 \mathrm{U} / \mu \mathrm{L})$ and $16 \mu \mathrm{L}$ of the PCR product. The digestion was performed according to the manufacturer's instructions. Reaction mixtures were incubated overnight at $37^{\circ} \mathrm{C}$. The total volume of each restriction-digested product was separated on a $1 \%(\mathrm{w} / \mathrm{v})$ agarose gel and subsequently photographed. According to ARDRA patterns, the strains were grouped into Operational Taxonomic Units (OTUs) according to Sessitsch et al. (2002).

\subsection{Sequencing and Phylogenetic Analysis}

The PCR products of 16S rDNA from each ARDRA pattern were selected for sequencing at Sangon Biotech Co., Ltd (Shanghai, China). All obtained sequences were compared with the sequences in the GenBank database using the BLASTN search program. The most similar sequences were further aligned using Clustal W software (Tompson et al., 1994). All reference sequences were obtained from the National Center for Biotechnology Information (NCBI). Phylogenetic trees were constructed using the neighbor-joining method with two-parameter MEGA software (version6.0) (Saitou \& Nei, 1987). Statistical significance levels of interior nodes were determined by bootstrap analysis (1,000 data resamplings) (Felsenstein, 1985).

\subsection{Nucleotide Sequence Accession Numbers}

The nucleotide sequences of the 16S rRNA gene for each analyzed strain have been deposited in GenBank and have been assigned accession numbers (Table 1).

\section{Results}

\subsection{Isolation of Endophytic Bacteria}

The surface sterilized seeds were divided into groups and then homogenized with sterile water. The homogenates were diluted and spread on LB agar plates. The plates were cultured at $37^{\circ} \mathrm{C}$ for $72 \mathrm{~h}$. Colonies with obvious morphological differences were purified. Colonies without morphological differences were randomly selected. A total of 137 colonies were isolated and purified.

\subsection{S rRNA Amplification and ARDRA Analysis}

A single colony was inoculated in LB broth and cultured at $37^{\circ} \mathrm{C}$ for $12 \mathrm{~h}$. The culture sample was used for DNA extraction. A pair of PCR primers (799f and 1492r) was used to amplify the 16S rRNA gene of the 137 isolates. Genomic DNA was used for the templates. The fragment size of 16S rDNA is approximately 700bp (Figure 1). The specific PCR product was completely digested with the restriction enzyme HaeIII. Based on ARDRA patterns, the isolated bacterial strains were grouped into different OTUs (Table 1). An OTU was defined as a group of clones with an identical banding patterns obtained from digestion. According to the ARDRA patterns (Figure 2), 137 strains were grouped into 9 OTUs.

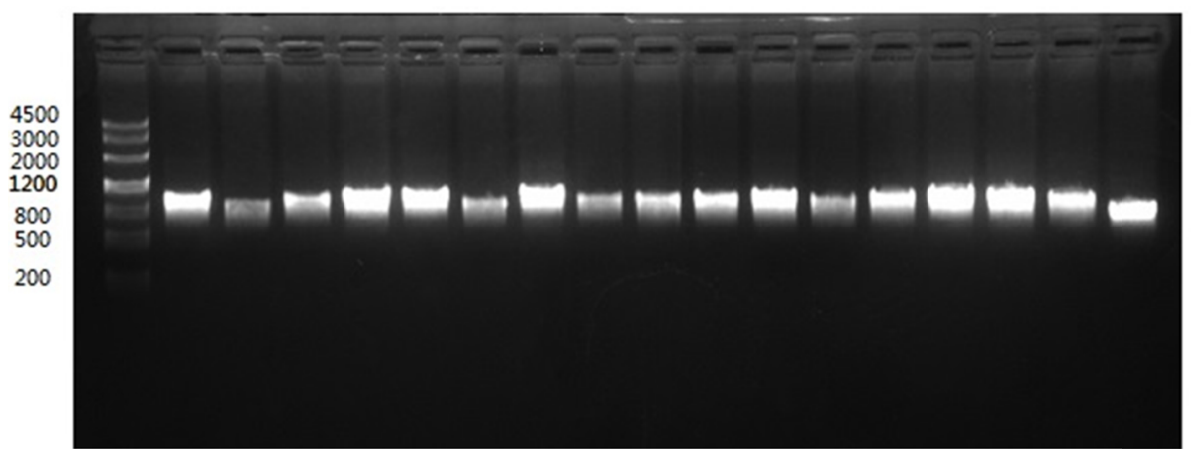

Figure 1. PCR amplification of the 16S rRNA gene

Note. The primers $799 \mathrm{f}$ and $1492 \mathrm{r}$ were used. Genomic DNA of endophytic bacteria was used as a template, and the annealing temperature of the PCR was $50{ }^{\circ} \mathrm{C}$. The predicted product was approximately $700 \mathrm{bp}$. 
Table 1. Number of phylotypes per OTU and their HaeIII patterns

\begin{tabular}{|c|c|c|c|}
\hline OTU Identification & Phylotypes ID & Amplified product (bp) & HaeIII pattern \\
\hline \multicolumn{4}{|l|}{$\gamma$-proteobacter } \\
\hline \multirow[t]{4}{*}{ Closest to Stenotrophomonas sp. } & WSDS 21 & 689 & $335,204,150$ \\
\hline & PL122 & 693 & $336,206,151$ \\
\hline & PL232 & 700 & $335,211,154$ \\
\hline & PL11 & 700 & $335,212,153$ \\
\hline \multirow[t]{5}{*}{ Closest to Pseudomonas sp. } & WSDS121 & 699 & $320,179,119,81$ \\
\hline & SLY22 & 703 & $321,179,122,81$ \\
\hline & SLY13 & 694 & $318,178,118,80$ \\
\hline & PL12 & 701 & $322,178,120,81$ \\
\hline & PL133 & 698 & $321,180,118,79$ \\
\hline \multirow[t]{4}{*}{ Closest to Uncultured bacterium } & YNZJ312 & 703 & $331,197,148,27$ \\
\hline & YNZJ323 & 699 & $328,201,141,29$ \\
\hline & SLY321 & 694 & $327,198,141,28$ \\
\hline & DYPE121 & 704 & $332,196,145,31$ \\
\hline Closest to Pectobacterium carotovorum subsp. & SLY33 & 699 & $446,244,9$ \\
\hline Closest to Yokenella regensburgei strain & MGJ121 & 682 & $357,201,79,33,12$ \\
\hline Closest to Citrobacter sp. & PL212 & 703 & $501,118,84$ \\
\hline Closest to Kluyvera ascorbata strain & MGJ136 & 700 & $357,217,126$ \\
\hline \multirow[t]{2}{*}{ Closest to Enterobacter sp. } & PL231 & 703 & $301,212,179,11$ \\
\hline & SLY32 & 703 & $302,211,179,11$ \\
\hline \multicolumn{4}{|l|}{ Firmicutes } \\
\hline Closest to Paenibacillus sp. & PL222 & 700 & $441,177,52,30$ \\
\hline
\end{tabular}

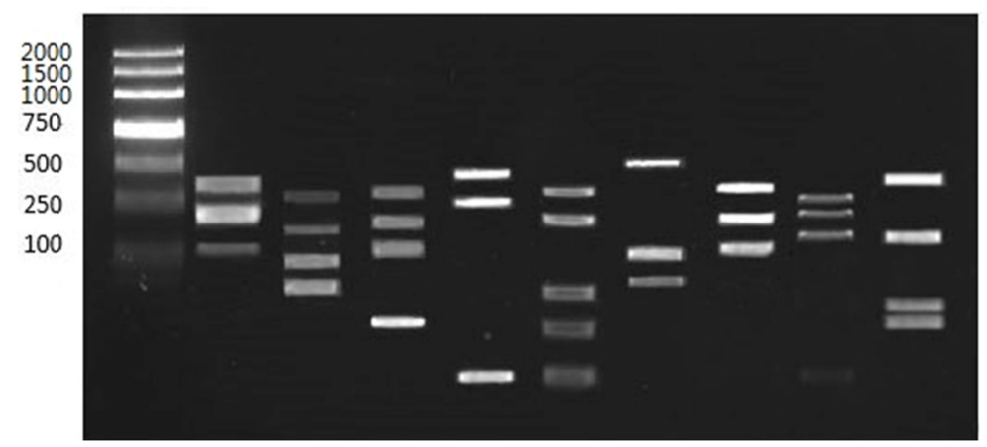

Figure 2. ARDRA analysis patterns of the 16S rDNA.

Note. The specific PCR products were completely digested using the restriction enzyme Hae III. The digested products were separated by electrophoresis. Strains with the same digestion patterns were grouped into OTUs.

\subsection{Diversity and Distribution Analysis of Endophytic Bacteria}

Representative isolates of specific groups were selected for sequencing and compared with the sequences in GenBank using the BLASTN search program. All isolates showed high similarities $(\geq 99 \%)$ with their closest related species. The details of representative strains are listed in Table 2. Sequence analysis revealed the bacterial diversity of $P$. notoginseng seeds. These strains contain 2 Gram-positive species in one genus and 135 Gram-negative species in eight genera, indicating the complexity of endophytic population present in the seeds of $P$. notoginseng plants. The relationship between the isolates and the reference species is shown in the phylogenetic tree (Figure 3). $\gamma$-proteobacteria was the most dominant group among the isolates (135 of 137 isolates) and comprised eight genera, with Pseudomonas being dominant (58 of 135 isolates). The second dominant genus was Enterobacter (20.4\%), followed by uncultured bacterium (14.6\%) and Stenotrophomonas $(10.2 \%)$. 
Table 2. Similarity of the $16 \mathrm{~S}$ rDNA sequences of partial endophytic bacterial strains from $P$. notoginseng seeds

\begin{tabular}{|c|c|c|c|c|}
\hline Group & $\begin{array}{l}\text { Isolates } \\
\text { (accession number) }\end{array}$ & No. of isolates & Closest relative (accession number) ${ }^{a}$ & Similarity (\%) \\
\hline \multirow[t]{19}{*}{$\gamma$-proteobacteria } & $\begin{array}{l}\text { WSDS21 } \\
(\text { KX688530) }\end{array}$ & 3 & $\begin{array}{l}\text { Stenotrophomonas maltophilia strain G10b } \\
\text { (KC136828.1) }\end{array}$ & 99 \\
\hline & $\begin{array}{l}\text { PL11 } \\
(\text { KX688526) }\end{array}$ & 4 & $\begin{array}{l}\text { Stenotrophomonas sp. REp-tet_144 } \\
\text { (JX899643.1) }\end{array}$ & 99 \\
\hline & $\begin{array}{l}\text { PL232 } \\
(\text { KX688525) }\end{array}$ & 5 & $\begin{array}{l}\text { Uncultured Stenotrophomonas sp. } \\
\text { (LC002923.1) }\end{array}$ & 99 \\
\hline & $\begin{array}{l}\text { PL122 } \\
(\text { KX688520) }\end{array}$ & 2 & $\begin{array}{l}\text { Stenotrophomonas maltophilia strain ZJB-14120 } \\
\text { (KM655831.1) }\end{array}$ & 99 \\
\hline & $\begin{array}{l}\text { WSDS121 } \\
(\mathrm{KX} 688529)\end{array}$ & 3 & $\begin{array}{l}\text { Pseudomonas sp. Tibet-YD5003-3 } \\
\text { (KF805078.1) }\end{array}$ & 99 \\
\hline & $\begin{array}{l}\text { SLY22 } \\
(\mathrm{KX} 688532)\end{array}$ & 4 & $\begin{array}{l}\text { Pseudomonas sp. BS29 } \\
\text { (KR063209.1) }\end{array}$ & 99 \\
\hline & $\begin{array}{l}\text { SLY13 } \\
(\mathrm{KX} 688533)\end{array}$ & 1 & $\begin{array}{l}\text { Pseudomonas sp. }+ \text { Y } 33 \\
\text { (JX113247.1) }\end{array}$ & 99 \\
\hline & $\begin{array}{l}\text { PL12 } \\
(\text { KX688521) }\end{array}$ & 26 & $\begin{array}{l}\text { Pseudomonas beteli strain RRLJ SMAR } \\
\text { (DQ299947.1) }\end{array}$ & 99 \\
\hline & $\begin{array}{l}\text { PL133 } \\
(\mathrm{KX} 688522)\end{array}$ & 24 & $\begin{array}{l}\text { Pseudomonas sp. PW49 } \\
\text { (KT726998.1) }\end{array}$ & 99 \\
\hline & $\begin{array}{l}\text { YNZJ312 } \\
(\mathrm{KX} 688537)\end{array}$ & 8 & $\begin{array}{l}\text { Uncultured bacterium clone Y1-5 } \\
\text { (JF766465.1) }\end{array}$ & 99 \\
\hline & $\begin{array}{l}\text { YNZJ323 } \\
(\mathrm{KX} 688538)\end{array}$ & 9 & $\begin{array}{l}\text { Uncultured bacterium clone M1_209_H3 } \\
\text { (JN683972.1) }\end{array}$ & 99 \\
\hline & $\begin{array}{l}\text { SLY321 } \\
(\mathrm{KX} 688535)\end{array}$ & 2 & $\begin{array}{l}\text { Uncultured bacterium clone } 3 Y-35 \\
\text { (EU786145.1) }\end{array}$ & 99 \\
\hline & $\begin{array}{l}\text { DYPE121 } \\
(\text { KX688536) }\end{array}$ & 1 & $\begin{array}{l}\text { Uncultured bacterium clone c93 } \\
\text { (KC954365.1) }\end{array}$ & 99 \\
\hline & $\begin{array}{l}\text { SLY33 } \\
(\mathrm{KX} 688534)\end{array}$ & 1 & $\begin{array}{l}\text { Pectobacterium carotovorum subsp. } \\
\text { carotovorum strain RN24 (KC790284.1) }\end{array}$ & 99 \\
\hline & $\begin{array}{l}\text { MGJ121 } \\
(\mathrm{KX} 688527)\end{array}$ & 2 & $\begin{array}{l}\text { Yokenella regensburgei strain NvH01 } \\
\text { (KJ397957.1) }\end{array}$ & 100 \\
\hline & $\begin{array}{l}\text { PL212 } \\
(\mathrm{KX} 688523)\end{array}$ & 7 & $\begin{array}{l}\text { Citrobacter sp. F41 } \\
\text { (FJ405282.1) }\end{array}$ & 99 \\
\hline & $\begin{array}{l}\text { MGJ136 } \\
\text { (KX688528) }\end{array}$ & 5 & $\begin{array}{l}\text { Kluyvera ascorbata strain IHB B } 7177 \\
\text { (KJ767338.1) }\end{array}$ & 99 \\
\hline & $\begin{array}{l}\text { PL231 } \\
\text { (KX688524) }\end{array}$ & 24 & $\begin{array}{l}\text { Enterobacter sp. HT-Z52-B2 } \\
(\text { KJ516915.1) }\end{array}$ & 100 \\
\hline & $\begin{array}{l}\text { SLY32 } \\
(\text { KX688531) }\end{array}$ & 4 & $\begin{array}{l}\text { Enterobacter aerogenes strain IEY } \\
\text { (GQ165811.1) }\end{array}$ & 100 \\
\hline Firmicutes & $\begin{array}{l}\text { PL222 } \\
\text { (KX688519) }\end{array}$ & 2 & $\begin{array}{l}\text { Paenibacillus sp. MC5-3 } \\
\text { (FJ932657.1) }\end{array}$ & 99 \\
\hline
\end{tabular}

Note. ${ }^{\text {a }}$ Closest relative species and its accession number in the $16 \mathrm{~S}$ rDNA sequence database. 


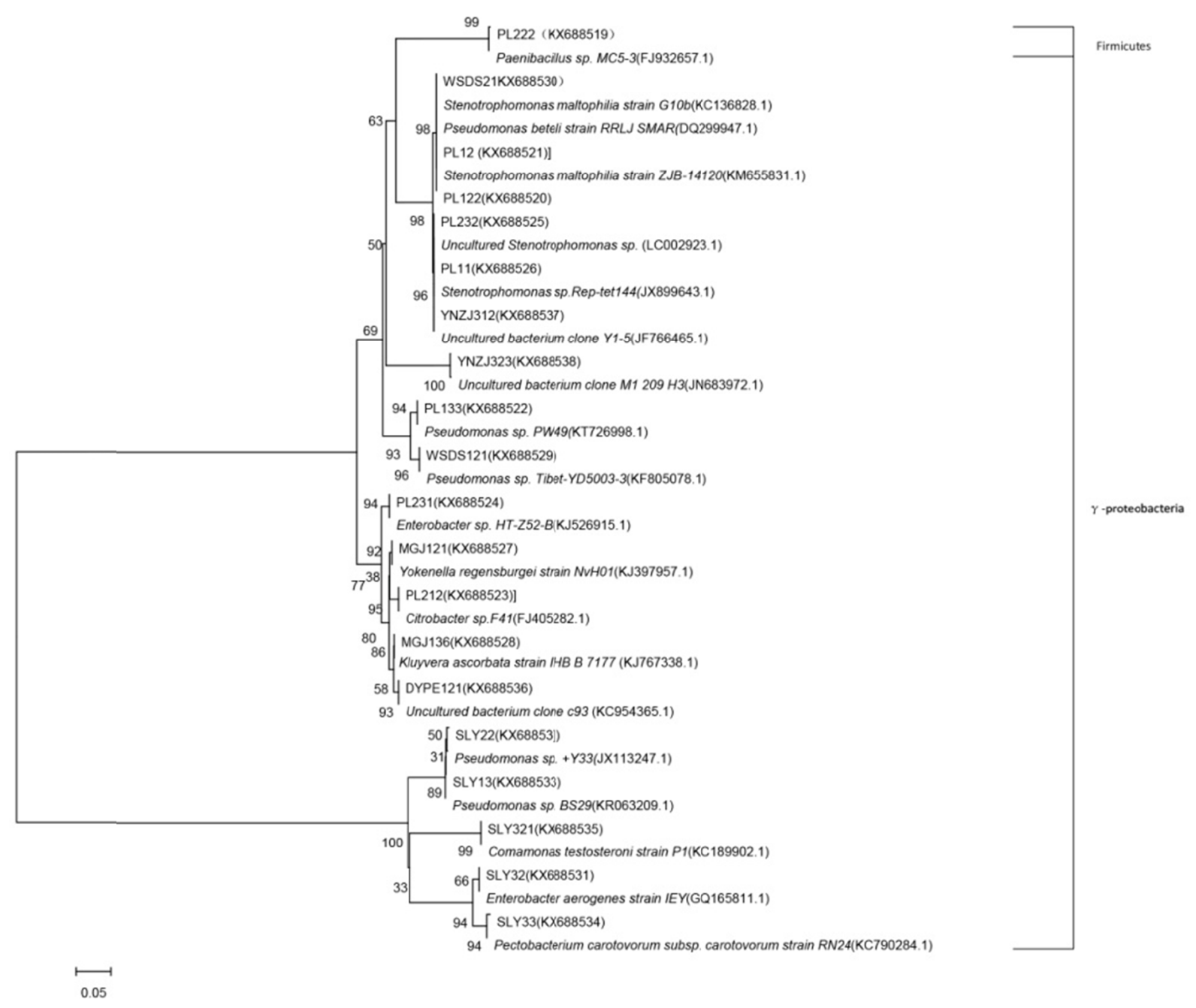

Figure 3. Phylogenetic tree based on partial 16S rDNA sequences of the endophytic bacteria of the $P$. notoginseng seeds using the neighbor-joining method

Note. The numbers in round brackets indicate the accession number in GenBank. The numbers at branch points indicate the bootstrap threshold (samples drawn 1000 times). Scale bar, 0.05 substitutions per base position.

The diversity of the endophytic bacteria of $P$. notoginseng plants was assessed using the seeds collected from the following six growing areas of the Wenshan region: Panlong of Yanshan (PL), Wenshandongshan of Wenshan (WSDS), Zhujie of Guangnan (ZJ), Hanqing of Maguan (MG), Shuanglongying of Qiubei (SLY), and Xichou (DYPE). The Pseudomonas genus showed a predominant existence and wide distribution in seeds collected from three places, which included Panlong of Yanshan, Wenshandongshan of Wenshan and Shuanglongying of Qiubei. Both the second and the third dominant genera, Enterobacter and Stenotrophomonas, were isolated from Panlong of Yanshan and Shuanglongying of Qiubei. The most endophytic bacteria isolates (94 of 137 isolates) originated from Panlong of Yanshan. With the exception of Panlong, the highest number of species (5 of 9 species) occurred in the seeds collected from Shuanglongying of Qiubei.

\section{Discussion}

Molecular approaches based on 16S rRNA gene analysis have been successfully used for bacterial community analysis. The ARDRA technique has been widely applied in genetic diversity studies of rhizobacteria (Dellagnezze et al., 2016; Mehri et al., 2011; Nievas et al., 2012; Santoro et al., 2016; Sanyal et al., 2016). In the present study, ARDRA analysis was applied to group the endophytic bacterial strains into different OTUs. The sequencing of 16S rDNA proved that each representative strain from each OTU represents a genus. The results suggest that this method is accurate and effective for the isolation and identification of the endophytic bacteria 
from $P$. notoginseng seeds, provides a preliminary screening before sequencing and avoids several rounds of sequencing.

Endophytes have been considered as abundant sources for probiotics. Ratnaweera et al. (2013) isolated eight endophytic fungi from Opuntia dillenii, seven of which exhibited antimicrobial activity. The most biologically active species is Fusarium sp., and the second most active is Aspergillus niger. Chadha et al. (2015) suggested that plant endophytic fungi can protect plants against various pathogen and pests and help plants survive under harsh biological or abiotic stresses. Tantirungkij et al. (2015) reported that rice leaves harbor several new yeast strains. Khan et al. (2015) isolated two fungal strains, Fusarium tricinctum RSF-4L and Alternaria alternata RSF-6L, which promote the growth of the host by phytohormone secretion. Ma et al. (2013) isolated endophytic bacteria from P. notoginseng, and 104 strains showed antagonism against Fusarium oxysporum, Ralstonia sp. and Meloidogyne hapla, which are three major pathogens associated with the root-rot disease complex of $P$. notoginseng. Shahzad et al. (2016) isolated an endophytic Bacillus amyloliquefaciens with the potential to produce gibberellins (GAs) and that plays a role in improving host-plant physiology.

In the present study, the bacterial endophytes isolated from the seeds of $P$. notoginseng belonged to four bacterial groups, including $\gamma$-proteobacteria and Firmicutes, Enterobacter, uncultured bacteria and Firmicutes. These results suggest that $P$. notoginseng seeds carry abundant microbial resources. Among the isolated bacteria, the dominant bacteria was Pseudomonas sp., followed by Enterobacter sp., uncultured bacteria clones, and Stenotrophomonas sp. To our knowledge, this report is the first comprehensive study on the isolation of endophytic bacteria from $P$. notoginseng seeds.

Strains isolated from the seeds may have biological activity against pathogens or perhaps are pathogens leading to diseases that occur during seed germination, seedling growth or plant development. Some Pseudomonas strains serve as plant growth-promoting rhizobacteria (PGPR) or biological control agents against plant pathogens (de Bruijn et al., 2007; Raaijmakers et al. 2010). Pseudomonas sp. is also one of bacterial pathogens that cause $P$. notoginseng root-rot disease (Miao et al., 2006). In the present study, the dominant endophytic bacteria were Pseudomonas sp. Whether the subsequent harboring of these Pseudomonas sp. strains leads to disease or plays a beneficial role on plants requires further research. Stenotrophomonas maltophilia has been reported to promote plant growth due to its production of phytohormones (Park et al., 2005; Naz et al., 2009) and to be a biological control agent due to its production of antibacterial compounds and secretion of fungicidal metabolites (Messiha et al., 2007; Taghavi et al., 2009). Pectobacterium carotovorum is a plant pathogen with a diverse host range and that causes bacterial soft rot (Mansfield et al., 2012). Enterobacter aerogenes is a nosocomial and pathogenic bacterium that causes opportunistic human infections. Whether these pathogens cause diseases on $P$. notoginseng remains unknown. Therefore, the isolation of these endophytic bacterial strains not only helps to further current understanding of the outbreak of seedling or plant diseases, but also provides good candidates for biological control against soil-borne root diseases.

\section{Acknowledgements}

This work was supported by the National Natural Science Foundation of China (31560246 and 31160020) and China Scholarship Council (201508535046).

\section{References}

Chadha, N., Mishra, M., Rajpal, K., Bajaj, R., Choudhary, D. K., \& Varma, A. (2015). An ecological role of fungal endophytes to ameliorate plants under biotic stress. Arch Microbiol, 197(7), 869-81. https://doi.org/10.1007/s00203-015-1130-3

Chelius, M. K., \& Triplett, E. W. (2001). The diversity of archaea and bacteria in association with the roots of Zea mays L. Microb Ecol, 41, 252-263. https://doi.org/10.1007/s002480000087

Cho, K. M., Hong, S. Y., Lee, S. M., Kim, Y. H., Kahng, G. G., Lim, Y. P., ... Yun, H. D. (2007). Endophytic bacterial communities in ginseng and their antifungal activity against pathogens. Microb Ecol, 54, 341-351. https://doi.org/10.1007/s00248-007-9208-3

de Bruijn, I., de Kock, M. J. D., Yang, M., de Waard, P., van Beek, T. A., \& Raaijmakers, J. M. (2007). Genome-based discovery, structure prediction and functional analysis of cyclic lipopeptide antibiotics in Pseudomonas species. Mol Microbiol, 63, 417-428. https://doi.org/10.1111/j.1365-2958.2006.05525.x

Dellagnezze, B. M., Vasconcellos, S. P., Melo, I. S., Santos Neto, E. V., \& Oliveira, V. M. (2016). Evaluation of bacterial diversity recovered from petroleum samples using different physical matrices. Braz J Microbiol, 47(3), 712-23. https://doi.org/10.1016/j.bjm.2016.04.004 
Felsenstein, J. (1985). Confidence limits on phylogenies: An approach using the bootstrap. Evolution, 39, 783-791. https://doi.org/10.2307/2408678

Feng, Y., Shen, D., \& Song, W. (2006). Rice endophyte Pantoea agglomerans YS19 promotes host plant growth and affects allocations of host photosynthates. J Appl Microbiol, 100, 938-945. https://doi.org/10.1111/ j.1365-2672.2006.02843.x

Hallmann, J., Quadt-Hallmann, A., Rodrguez-Kabana, R., \& Kloepper, J. W. (1998). Interactions between Meloidogyne incognita and endophytic bacteria in cotton and cucumber. Soil Biol Biochem, 30, 925-937. https://doi.org/10.1016/S0038-0717(97)00183-1

Khan, A. R., Ullah, I., Waqas, M., Shahzad, R., Hong, S. J., Park, G. S., ... Shin, J. H. (2015). Plant growth-promoting potential of endophytic fungi isolated from Solanum nigrum leaves. World J Microbiol Biotechnol, 31(9), 1461-6. https://doi.org/10.1007/s11274-015-1888-0

Li, Y. H., Zhu, J. N., Zhai, Z. H., \& Zhang, Q. A. (2010). Endophytic bacterial diversity in roots of Phragmites australis in constructed Beijing Cuihu Wetland (China). FEMS Microbiol Lett, 309, $84-93$. https://doi.org/10.1111/j.1574-6968.2010.02015.x

Lodewyck, C., Vangronsveld, J., Porteous, F., Moore, E. R. B., Taghavi, S., Mezgeay, M., \& van der Lelie, D. (2002). Endophytic bacteria and their potential application. Crit Rev Plant Sci, 86(6), 583-606. https://doi.org/10.1080/0735-260291044377

Ma, L., Cao, Y. H., Cheng, M. H., Huang, Y., Mo, M. H., Wang, Y., Yang, J. Z., \& Yang, F. X. (2013). Phylogenetic diversity of bacterial endophytes of Panax notoginseng with antagonistic characteristics towards pathogens of root-rot disease complex. Antonie Van Leeuwenhoek, 103(2), $299-312$. https://doi.org/10.1007/s10482-012-9810-3

Mansfield, J., Genin, S., Magori, S., Citovsky, V., Sriariyanum, M., Ronald, P., ... Foster, G. D. (2012). Top 10 plant pathogenic bacteria in molecular plant pathology. Mol Plant Pathol, 13, 614-629. https://doi.org/10.1111/j.1364-3703.2012.00804.x

Mehri, I., Turki, Y., Chair, M., Chérif, H., Hassen, A., Meyer, J. M., \& Gtari, M. (2011). Genetic and functional heterogeneities among fluorescent Pseudomonas isolated from environmental samples. J Gen Appl Microbiol, 57, 101-114. https://doi.org/10.2323/jgam.57.101

Messiha, N. A. S., Van Diepeningen, A. D., Farag, N. S., Abdallah, S. A., Janse, J. D., \& Van Bruggen, A. H. C. (2007). Stenotrophomonas maltophilia: a new potential biocontrol agent of Ralstonia solanacearum, causal agent of potato brown rot. Eur J Plant Pathol, 118, 211-225. https://doi.org/10.1007/s10658-007-9136-6

Miao, Z. Q, Li, S. D., Liu, X. Z., Chen, Y. J., Li, Y. H., Wang, Y., ... Zhang, K. Q. (2006). The causal microorganisms of Panax notoginseng root rot disease. Sci Agric Sin, 39, 1371-1378.

Naz, I., Bano, A., \& Hassan, T. U. (2009). Isolation of phytohormones producing plant growth promoting rhizobacteria from weeds growing in Khewra salt range, Pakistan, and their implication in providing salt tolerance to Glycine max L. Afr J Biotechnol, 8, 5762-5768. https://doi.org/10.5897/AJB09.1176

Nievas, F., Bogino, P., Nocelli, N., \& Giordano, W. (2012). Genotypic analysis of isolated peanut-nodulating rhizobial strains reveals differences among populations obtained from soils with different cropping histories. Appl Soil Ecol, 53, 74-82. https://doi.org/10.1016/j.apsoil.2011.11.010

Park, M., Kim, C., Yang, J., Lee, H., Shin, W., Kim, S., \& Sa, T. (2005). Isolation and characterization of diazotrophic growth promoting bacteria from rhizosphere of agricultural crops of Korea. Microbiol Res, 160(2), 127-33. https://doi.org/10.1016/j.micres.2004.10.003

Patkowska, E. (2001). Formation of bacterial and fungal communities in the rhizosphere of soybean [Glycine max. [L.] Merrill] and their antagonism towards phytopathogens. J Plant Prot Res, 41(2), 181-191.

Raaijmakers, J. M., de Bruijn, I., Nybroe, O., \& Ongena, M. (2010). Natural functions of lipopeptides from Bacillus and Pseudomonas: More than surfactants and antibiotics. FEMS Microbiol Rev, 34, 1037-1062. https://doi.org/10.1111/j.1574-6976.2010.00221.x

Ratnaweera, P. B., de Silva, E. D., Williams, D. E., \& Andersen, R. J. (2015) Antimicrobial activities of endophytic fungi obtained from the arid zone invasive plant Opuntia dillenii and the isolation of equisetin, from endophytic Fusarium sp. BMC Complement Altern Med, 15, 220. https://doi.org/10.1186/ s12906-015-0722-4 
Saitou, N., \& Nei, M. (1987). The neighbor-joining method: A new method for reconstructing phylogenetic trees. Mol Biol Evol, 4, 406-425.

Santoro, M. V., Bogino, P. C., Nocelli, N., Cappellari Ldel, R., Giordano, W. F., \& Banchio, E. (2016). Analysis of plant growth-promoting effects of fluorescent Pseudomonas strains isolated from Mentha piperita rhizosphere and effects of their volatile organic compounds on essential oil composition. Front Microbiol, 7, 1085. https://doi.org/10.3389/fmicb.2016.01085

Sanyal, S. K., Mou, T. J., Chakrabarty, R. P., Hoque, S., Hossain, M. A., \& Sultana, M. (2016). Diversity of arsenite oxidase gene and arsenotrophic bacteria in arsenic affected Bangladesh soils. AMB Express, 6, 21. https://doi.org/10.1186/s13568-016-0193-0

Schulz, B., Wanke, U., Draeger, S., \& Aust, H. J. (1993). Endophytes from herbaceous plants and shrubs: effectiveness of surface sterilization methods. Mycol Res, 97, 1447-1450. https://doi.org/10.1016/ S0953-7562(09)80215-3

Senthilkumar, M., Anandham, R., Madhaiyan, M., Venkateswaran, V., \& Tongmin, Sa. (2011). Endophytic bacteria: perspectives and applications in agricultural crop production. In D. K. Maheshwari (Ed.), Bacteria in agrobiology: Crop ecosystems. Springer, Berlin. https://doi.org/10.1007/978-3-642-18357-7_3

Sessitsch, A., Reiter, B., Pfeifer, U., \& Wilhelm, E. (2002). Cultivation independent population analysis of bacterial endophytes in three potato varieties based on eubacterial and Actinomycetes-specific PCR of $16 \mathrm{~S}$ rDNA genes. FEMS Microbiol Ecol, 39, 23-32. https://doi.org/10.1111/j.1574-6941.2002.tb00903.x

Shahzad, R., Waqas, M., Khan, A. L., Asaf, S., Khan, M. A., Kang, S. M., ... Lee, I. J. (2016). Seed-borne endophytic Bacillus amyloliquefaciens RWL-1 produces gibberellins and regulates endogenous phytohormones of Oryza sativa. Plant Physiol Biochem, 106, 236-43. https://doi.org/10.1016/ j.plaphy.2016.05.006

Sturz, A. V., Christie, B. R., \& Nowak, J. (2000). Bacterial endophytes: Potential endophytes: Potential role in developing sustainable systems of crop production. Crit Rev Plant Sci, 19, 1-30. https://doi.org/10.1016/ S0735-2689(01)80001-0

Sun, H. X., Qin, F., \& Ye, Y. P. (2005). Relationship between haemolytic and adjuvant activity and structure of protopanaxadiol-type saponins from the roots of Panax notoginseng. Vaccine, 23, 533-5542. https://doi.org/10.1016/j.vaccine.2005.07.036

Sun, J. H., Ma, N., Chen, Z. J., Wang, C. L., \& Cui, X. M. (2004). Effects of root rot on saponin content in Panax notoginseng. J Chin Medicinal Mater, 27, 79-80.

Taghavi, S., Garafola, C., Monchy, S., Newman, L., Hoffman, A., Weyens, N., ... van der Lelie, D. (2009). Genome survey and characterization of endophytic bacteria exhibiting a beneficial effect on growth and development of poplar trees. Appl Environ Microbiol, 75, 748-757. https://doi.org/10.1128/AEM.02239-08

Tantirungkij, M., Nasanit, R., \& Limtong, S. (2015). Assessment of endophytic yeast diversity in rice leaves by a culture-independent approach. Antonie Van Leeuwenhoek, 108(3), 633-47. https://doi.org/10.1007/ s10482-015-0519-y

Tompson, J. D., Higgins, D. G., \& Gibson, T. J. (1994). CLUSTAL W: Improving the sensitivity of progressive multiple sequence alignment through sequence weighting, position-specific gap penalties and weight matrix choice. Nucleic Acids Res, 22, 4673-4680. https://doi.org/10.1093/nar/22.22.4673

Vendan, R. T., Yu, Y. J., Lee, S. H., \& Rhee, Y. H. (2010). Diversity of endophytic bacteria in ginseng and their potential for plant growth promotion. J Microbiol, 48, 559-565. https://doi.org/10.1007/s12275-010-0082-1

\section{Copyrights}

Copyright for this article is retained by the author(s), with first publication rights granted to the journal.

This is an open-access article distributed under the terms and conditions of the Creative Commons Attribution license (http://creativecommons.org/licenses/by/4.0/). 